\title{
Mechanisms of Change in Emulsifying Capacity Induced by Protein Denaturation and Aggregation in Quick-Frozen Pork Patties with Different Fat Levels and Freeze-Thaw Cycles
}

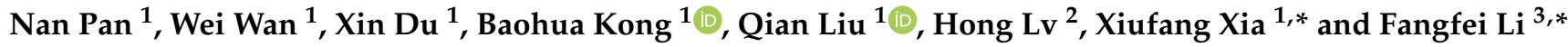 \\ 1 College of Food Science, Northeast Agricultural University, Harbin 150030, China; pannan36@163.com (N.P.); \\ ww2417013241@163.com (W.W.); dbnydxdx@163.com (X.D.); kongbh63@hotmail.com (B.K.); \\ liuqian@neau.edu.cn (Q.L.) \\ 2 Department of Food and Pharmaceuticals, Harbin Light Industry School, Harbin 150076, China; \\ lvhongq@126.com \\ 3 College of Forestry, Northeast Forestry University, Harbin 150040, China \\ * Correspondence: xiaxiufang@neau.edu.cn (X.X.); lifangfei33@163.com (F.L.); Tel.: +86-451-55191289 (X.X.); \\ $+86-451-82190222$ (F.L.)
}

Citation: Pan, N.; Wan, W.; Du, X.; Kong, B.; Liu, Q.; Lv, H.; Xia, X.; Li, F. Mechanisms of Change in Emulsifying Capacity Induced by Protein Denaturation and Aggregation in Quick-Frozen Pork Patties with Different Fat Levels and Freeze-Thaw Cycles. Foods 2022, 11, 44. https://doi.org/10.3390/ foods11010044

Academic Editor: Manuel Castillo Zambudio

Received: 14 October 2021 Accepted: 9 December 2021 Published: 24 December 2021

Publisher's Note: MDPI stays neutral with regard to jurisdictional claims in published maps and institutional affiliations.

Copyright: (c) 2021 by the authors. Licensee MDPI, Basel, Switzerland. This article is an open access article distributed under the terms and conditions of the Creative Commons Attribution (CC BY) license (https:// creativecommons.org/licenses/by/ $4.0 /)$.

\begin{abstract}
Herein, we discuss changes in the emulsifying properties of myofibrillar protein (MP) because of protein denaturation and aggregation from quick-frozen pork patties with multiple fat levels and freeze-thaw (F-T) cycles. Protein denaturation and aggregation were confirmed by the significantly increased surface hydrophobicity, turbidity, and particle size, as well as the significantly decreased solubility and absolute zeta potential, of MPs with increases in fat levels and F-T cycles $(p<0.05)$. After multiple F-T cycles, the emulsifying activity and emulsion stability indices of all samples were significantly reduced $(p<0.05)$. The emulsion droplets of MP increased in size, and their distributions were dense and irregular. The results demonstrated that protein denaturation and aggregation due to multiple F-T cycles and fat levels changed the distribution of surface chemical groups and particle sizes of protein, thus affecting the emulsifying properties.
\end{abstract}

Keywords: emulsifying property; myofibrillar protein; protein denaturation and aggregation; quickfrozen patties; freeze-thaw cycle

\section{Introduction}

Quick-frozen patties are a type of emulsion-type comminuted meat product [1]. They are usually composed of muscle proteins, fat particles, water, salt, and nonmeat ingredients combined by mincing, chopping, mixing, molding, quick freezing, and frozen storage. In the emulsified meat system, muscle proteins and fat particles are important components. For muscle proteins, myofibrillar protein (MP), which forms $55-60 \%$ of total protein, plays an important role in emulsifying properties, and more than $90 \%$ of these proteins participate in the emulsification processes [2,3]. MP acts as an emulsifier to maintain the balance of protein-fat and protein-water by adsorbing on the surface of fat globules to form the interfacial protein film [1]. Fat particles are another important ingredient for improving the quality of emulsified meat products [4]. Fat droplets are entrapped in the protein matrix and stabilized via a protein network structure [1]. The addition of fat contributes to the formation of a stable meat emulsion and the enhancement of the flavor, juiciness, and textural properties of emulsified meat products [5]. In addition to muscle proteins and fat particles, protein composition, type (such as cereal protein and whey protein), and processing conditions (such as thermal treatment [6], $\mathrm{pH}$ [7], mechanical stress [8], and frozen storage [9]) influence the emulsifying properties of proteins.

Quick freezing and frozen storage are the most extensively used methods for extending the shelf-life of quick-frozen patties [10]. Thawing is a common and key step before quickfrozen patties are further processed and consumed [11]. When the cold chain is unsound, 
temperature variation during freezing, frozen storage, thawing, and transportation can induce freeze-thaw (F-T) cycles $[10,12]$. During F-T cycles, the integrity of minced fat and lean meat from patties is destroyed, and some reactive oxygen species are released, which could intensify fat and protein oxidation [13]. Oxidation could induce protein conformational partial unfolding, thereby increasing the extent of exposed hydrophobic groups that were buried in the protein [14]. Furthermore, protein denaturation due to oxidative reactions and the formation of protein aggregates via hydrophobic interactions is accelerated by repeated F-T cycles [3,15].

Although the emulsification property of MP has been extensively discussed, there are few studies that have investigated the relationship among emulsifying properties, protein denaturation, and aggregation during multiple F-T cycles. Therefore, this study clarified the mechanism of decreased MP emulsification characteristics by analyzing the surface hydrophobicity and solubility and by determining the turbidity, particle size, and zeta potential of protein from patties with various fat levels.

\section{Materials and Methods}

\subsection{Materials}

Fresh pork ham and back fat were obtained from a local supermarket (Harbin, Heilongjiang, China) at $24 \mathrm{~h}$ postmortem. All chemicals reagents used were of analytical grade.

\subsection{Preparation and Repeated Freeze-Thaw Treatment of Patties}

Based on our previous study, various fat levels $(0 \%, 5 \%, 10 \%, 15 \%$, and 20\%) of patties were prepared, and a procedure of F-T cycles were performed [16]. Fresh pork ham muscle was trimmed of visible fat and connective tissues using a butcher knife. Lean meat and back fat were separately cut into small chunks and ground using a meat grinder equipped with a $0.5 \mathrm{~mm}$ plate (Braher International, San Sebastian, Spain). There were five different formulations with combinations of lean/fat as follows: 100/0\%, 95/5\%, 90/10\%, $85 / 15 \%$, and $80 / 20 \%$. During patty manufacturing, $2 \% \mathrm{NaCl}$ and $20 \%$ ice-cold water were incorporated into the meat mixture for each fat level. Finally, patties were individually wrapped in polyethylene bags. There were 60 patties (approximately $100 \mathrm{~g}$ each). All patties were separated into five groups, and each of them underwent F-T cycles. Samples subjected to 1, 3, and 5 F-T cycles were used for experiments. There were three independent batches of patties, and each parameter was measured in triplicate.

\subsection{Isolation of $M P$}

MP extraction was performed on the patties following F-T cycles as described by Li et al. [15]. Patties were homogenized 3 times with 4 vol (w/v) cold-extracted solution (10 mM sodium phosphate, $0.1 \mathrm{M} \mathrm{NaCl}, 2 \mathrm{mM} \mathrm{MgCl}_{2}$, and $1 \mathrm{mM} \mathrm{EGTA}, \mathrm{pH}=7.0$ ) for $1 \mathrm{~min}$ with a tissue homogenizer ( $\mathrm{Lu}$ Shen Instrument Equipment, Shanghai, China). The mixture was centrifuged at $6500 \times g$ for $15 \mathrm{~min}$ at $4{ }^{\circ} \mathrm{C}$. The obtained pellet was then washed three times with $4 \mathrm{vol}$ of $0.1 \mathrm{M} \mathrm{NaCl}$ under the same condition as above, except that in the last wash, the myofibril suspension was filtered through four layers of cheese cloth to remove connective tissue, and its $\mathrm{pH}$ was adjusted to 6.0 with $0.1 \mathrm{M} \mathrm{HCl}$ prior to centrifugation. The obtained MP extractions were kept at $4{ }^{\circ} \mathrm{C}$ and used within $48 \mathrm{~h}$. The biuret method was used to determine the protein concentration.

\subsection{Determination of Protein Denaturation}

\subsubsection{Protein Surface Hydrophobicity}

Protein surface hydrophobicity was determined as per Benjakul et al. [17] using 1anilino-8-naphthalenesulfonate (ANS) (Sigma Aldrich Chemical Co.(St. Louis, MO, USA)) as a fluorescence probe using a fluorescence spectrophotometer (F-4500, Hitachi, Tokyo, Japan). The MP solution was adjusted to $0.08,0.16,0.24,0.32$, and $0.4 \mathrm{mg} / \mathrm{mL}$ using $15 \mathrm{mM}$ of piperazine-N,N'-bis-2-ethanesulphonic acid (PIPES) buffer (0.6 M NaCl; pH 6.25) in a total volume of $4 \mathrm{~mL}$. Then, $40 \mu \mathrm{L}$ of ANS $(8 \mathrm{mM})$ was mixed with the solution under dark 
conditions at $25{ }^{\circ} \mathrm{C}$ for $20 \mathrm{~min}$. The excitation and emission wavelengths were 370 and $470 \mathrm{~nm}$, respectively, with a slit width of $5 \mathrm{~nm}$. For each sample, surface hydrophobicity was determined from the initial slope of net relative fluorescence.

\subsubsection{Protein Solubility}

Protein solubility was analyzed by the methods of Wang et al. [18]. Note that $10 \mathrm{~mL}$ of MP suspension $(2 \mathrm{mg} / \mathrm{mL})$ was centrifuged at $5000 \times g$ for $15 \mathrm{~min}$ at $4{ }^{\circ} \mathrm{C}$. Protein solubility $(\%)$ is the percentage of supernatant protein concentration and protein concentration before centrifugation.

\subsection{Determination of Protein Aggregation}

\subsubsection{Protein Turbidity Determination}

Protein turbidity was analyzed using the absorbance method according to Pan et al. [19]. The MP dispersions were dissolved in $15 \mathrm{mM}$ of PIPES buffer solution $(0.6 \mathrm{M} \mathrm{NaCl}, \mathrm{pH}$ 6.25) to obtain a concentration of $1 \mathrm{mg} / \mathrm{mL}$. The absorbance of the sample was measured at a $660 \mathrm{~nm}$ wavelength using a $720 \mathrm{G}$ visible spectrophotometer (Shanghai Yidian Analytical Instrument Co., Ltd., Shanghai, China). Turbidity was expressed as the absorbance value.

\subsubsection{Particle Size Analysis}

The Mastersizer 2000 (Malvern Instruments Ltd., Worcestershire, UK) was used to monitor particle size and particle size distribution by preparing MP solution. The MP dispersions were diluted to $1 \mathrm{mg} / \mathrm{mL}$ with deionized water to avoid multiple scattering. One milliliter of MP solution was added into a clear zeta cell. Size measurements were reported as the volume-weighted mean diameter $\left(d_{4,3}\right)$ (Equation (1)) and surface-weighted mean diameter $\left(d_{3,2}\right)$ (Equation (2)). The indexes of protein were analyzed using the Malvern Mastersizer software (version 5.12c, Malvern Instruments Co. Ltd., Worcestershire, UK) [15]

$$
\begin{aligned}
& d_{4,3}=\frac{\sum n_{i} d_{i}^{4}}{\sum n_{i} d_{i}^{3}}(\mu m) \\
& d_{3,2}=\frac{\sum n_{i} d_{i}^{3}}{\sum n_{i} d_{i}^{2}}(\mu m)
\end{aligned}
$$

where $n_{i}$ is the number of droplets of diameter $d_{i}$.

\subsubsection{Zeta Potential Analysis}

Zeta potential was determined by the methods of Zhang et al. [20], with minor modifications. Protein dispersions were diluted to $1 \mathrm{mg} / \mathrm{mL}$ with deionized water to avoid the scattering effect. About $1 \mathrm{~mL}$ of MP solution was used for testing, and the average measurement was 6 . The value was obtained by a zeta potential analyzer (Malvern Instruments Co. Ltd., Worcestershire, UK) at $25^{\circ} \mathrm{C}$ and expressed in $\mathrm{mV}$.

\subsection{Emulsifying Properties}

\subsubsection{Emulsifying Activity Index and Emulsion Stability Index}

Both emulsifying activity index (EAI) and emulsion stability index (ESI) were measured as per the method of Pearce and Kinsella [21]. Protein dispersions were diluted to $1 \mathrm{mg} / \mathrm{mL}$ with $15 \mathrm{mM}$ of PIPES buffer solution $(0.6 \mathrm{M} \mathrm{NaCl}, \mathrm{pH} 6.25)$. Note that $2 \mathrm{~mL}$ of soy oil and $8 \mathrm{~mL}$ of protein solution $(1 \mathrm{mg} / \mathrm{mL}, w / v)$ were homogenized at $1200 \mathrm{rpm}$ for $1 \mathrm{~min}$ using a homogenizer blender (Model T25 D S-25, IKA, DE). Then, emulsion (50 $\mu \mathrm{L}$ ) was taken at $0.5 \mathrm{~cm}$ from the bottom of the plastic tube and diluted with $5 \mathrm{~mL}$ of $0.1 \%$ sodium dodecyl sulphate (SDS) solution at 0 and $10 \mathrm{~min}$ after homogenization. The absorbances of different emulsions at $500 \mathrm{~nm}$ were measured using a UT-1800 spectrophotometer (Beijing 
Purkinje General Instrument Co., Ltd., Beijing, China). SDS solution $(0.1 \%, w / v)$ was used as a blank. The EAI and ESI were calculated as:

$$
\begin{gathered}
E A I\left(\mathrm{~m}^{2} / \mathrm{g}\right)=\frac{2 \times 2.303}{\mathrm{c} \times(1-\varphi) \times 10^{4}} \times A_{0} \times \text { dilution } \\
E S I(\%)=\frac{A_{10}}{A_{0}} \times 100
\end{gathered}
$$

where $\mathrm{c}$ is the protein concentration before emulsification $(\mathrm{mg} / \mathrm{mL}), \varphi$ is the oil volume fraction $(v / v)$ of emulsion (0.25), dilution is 100 , and $A_{0}$ and $A_{10}$ are the absorption at 0 and $10 \mathrm{~min}$, respectively.

\subsubsection{Microstructure of Emulsion}

As shown in Section 2.5.1, a small drop of emulsion was obtained and immediately observed using an optical microscope (Labomed Lx400, Labo America, Inc., Fremont, CA, USA) with objective lenses of $40 \times$. For capturing images of the emulsion, a digital camera connected to the microscope was used. The diameter of protein emulsion droplets was analyzed using Image-pro plus (Media Cybernetics, Silver Spring, MD, USA).

\subsection{Statistical Analysis}

All experiments were performed in three replicates with triplicate measurements for each sample. All data were represented as the mean \pm standard error (SE) and calculated using Statistix 8.1 software package with the General Linear Models procedure (Analytical Software, St Paul, MN, USA). Moreover, to determine significant differences among means, one-way analysis of variance (ANOVA) with Tukey's multiple comparisons was used $(p<0.05)$. The graphs were obtained using Sigma plot 12.5. Principal component analysis (PCA) was performed among the indicators (surface hydrophobicity, protein solubility, $d_{4,3}$, $d_{3,2}$, zeta potential, protein turbidity, droplet diameter, EAI and ESI), as well as between the indicators and different F-T cycles, using IBM SPSS Statistics version 22.0 (Tulsa, OK, USA) to identify similarities and differences between samples.

\section{Results and Discussion}

\subsection{Protein Denaturation}

\subsubsection{Protein Surface Hydrophobicity}

Surface hydrophobicity reflects minor changes in the chemical and physical states of proteins, which could be an important parameter for evaluating protein denaturation [22]. Moreover, surface hydrophobicity is related to the functional properties of proteins, such as solubility and emulsifying property [23]. As shown in Figure 1A, the surface hydrophobicity of MP from all samples with the same fat levels significantly increased after five F-T cycles $(p<0.05)$. The results indicated that the interaction between proteins changed from hydrophilic to hydrophobic. Generally, hydrophobic amino acids were occluded in the core of protein molecules and located in the cavities of hydrophobic binding between proteins [24,25]. With increasing F-T cycles, the structure and conformation of protein molecules were unfolded, and certain hydrophobic groups were exposed to the polar environments of the protein surface step by step, which accelerated the opening of the interior hydrophobic domain and subsequently enhanced the hydrophobicity of the protein surface [3].

When the F-T cycles were the same, the surface hydrophobicity of samples demonstrated a considerable increase with increased fat levels $(p<0.05)$. In particular, in samples with $20 \%$ fat at the fifth F-T cycle, surface hydrophobicity increased by $23.24 \%$ compared with samples without added fat. The results were attributed to lipid oxidation, which intensified the degree of protein oxidation. Oxidative processes could change protein conformation, thus leading to the exposure of hydrophobic groups hidden in proteins $[3,16]$. Similar results were obtained by $\mathrm{Fu}$ et al. [26], who demonstrated that there was a sig- 
nificant increase in the surface hydrophobicity of beef protein with increases in oxidant concentration. Furthermore, Xia et al. [27] reported that protein with a higher surface hydrophobicity could increase protein sensitivity to denaturation. The denatured MP directly affected the protein structure [28]. Riebroy et al. [29] obtained a similar result that increased surface hydrophobicity of fish protein was related to the greater exposure of hydrophobic groups, which subsequently promoted protein denaturation and subsequent aggregation in turn.

\subsubsection{Protein Solubility}

Protein solubility, which is the most practical indicator to show protein denaturation and aggregation, refers to the ability of proteins to be dispersed in water [30,31]. As shown in Figure 1B, in samples with the same fat levels, the solubility of MP significantly decreased with increases in the number of F-T cycles $(p<0.05)$. Furthermore, in samples with $20 \%$ fat level at the fifth F-T cycle, protein solubility decreased by $34.41 \%$ compared with samples without added fat. Li et al. [32] reported that the decrease in solubility from fish protein subjected to F-T cycles might be attributed to the formation of high-molecular weight aggregates (>200 kDa). Moreover, protein solubility depends on the balance between protein-protein and protein-solvent interactions [33]. When samples were subjected to repeated freezing and thawing processes, protein conformation was partially unfolded because of hydrophobic interactions, which reduced the protein-water interaction and hence decreased protein solubility [34]. The results negatively correlated with changes in protein surface hydrophobicity (Figure 1A). Zhou and Yan [35] reported that with increase in exposure of hydrophobic groups, the solubility of proteins was reduced. Shen et al. [36] confirmed that a decline in solubility of porcine protein was accompanied by the exposure of hydrophobic groups.

With increases in fat level, the protein solubility of samples with the same F-T cycles exhibited an increasing tendency. Previously, our studies confirmed that lipid oxidation could increase the extent of protein oxidation, which led to the exposure of a large number of intra/intermolecular S-S bonds and hydrophobic groups and thus promoted protein cross-linking and the formation of insoluble aggregates [16]. Both hydrophobic regions and insoluble aggregates could result in a reduction in protein solubility. Lv et al. [37] obtained similar results in that the solubility of MP oxidized by malondialdehyde was considerably less.

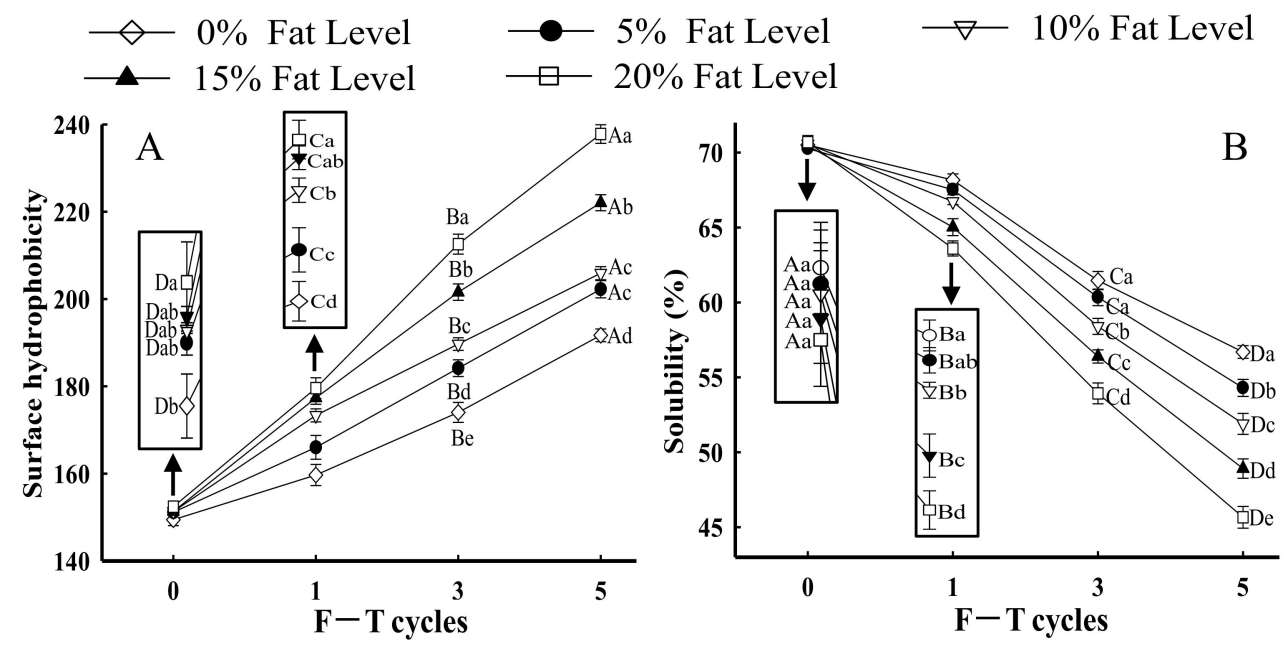

Figure 1. Influence of F-T cycles on surface hydrophobicity (A) and solubility (B) of myofibrillar protein from quick-frozen patties with different fat levels. Values are given as the mean $\pm \mathrm{SE}$. The means for the same fat levels with different uppercase letters (A to D) and the same F-T cycles with different lowercase letters (a to e) differed significantly $(p<0.05)$. 


\subsection{Protein Aggregation}

\subsubsection{Particle Size Analysis}

The particle size of a protein is an important parameter for evaluating protein aggregation behavior [38]. Changes in particle size distribution and average particle size $\left(d_{4,3}\right.$ and $d_{3,2}$ ) helped evaluate the particle size of proteins. As shown in Figure 2, a monomodal distribution of peaks was observed for all samples. With increases in fat levels and F-T cycles, the peak of MP samples shifted to a more extensive size range, their distribution became gradually wider, and the peak height gradually reduced. This phenomenon could be explained by the fact that fat oxidation increased the protein oxidation rate during $\mathrm{F}-\mathrm{T}$ cycles, and soluble aggregates were then formed by covalent cross-linking at first. As the degree of oxidation increased, certain insoluble aggregates were formed. Thus, an extensive size range and a wide peak were identified [39]. Furthermore, with increases in the number of F-T cycles, the protein structure gradually unfolded, which subsequently participated in the processes of protein aggregation and led to a larger particle size monomodal distribution [16].

The particle sizes of $d_{4,3}$ and $d_{3,2}$ of MP solution significantly increased to 56.54 and $23.38 \mu \mathrm{m}$, respectively, as the fat level increased to $20 \%$ after five F-T cycles $(p<0.05)$ (Table 1). This indicated the occurrence of large aggregation or coalescence between proteins. The increase in particle size could be explained by the fact that protein denaturation and oxidative reaction during F-T cycles increased the generation of aggregates via intra/intermolecular disulfides and dityrosine cross-links [40,41]. Wang et al. [42] obtained similar results, showing that an increase in particle size from quick-frozen yellow croaker MP solution was attributed to the formation of protein polymers after protein denaturation and oxidation. Shen et al. [36] reported that hydrophobic interactions enhanced interactions between proteins and then produced large aggregates, which resulted in an increase in particle size.
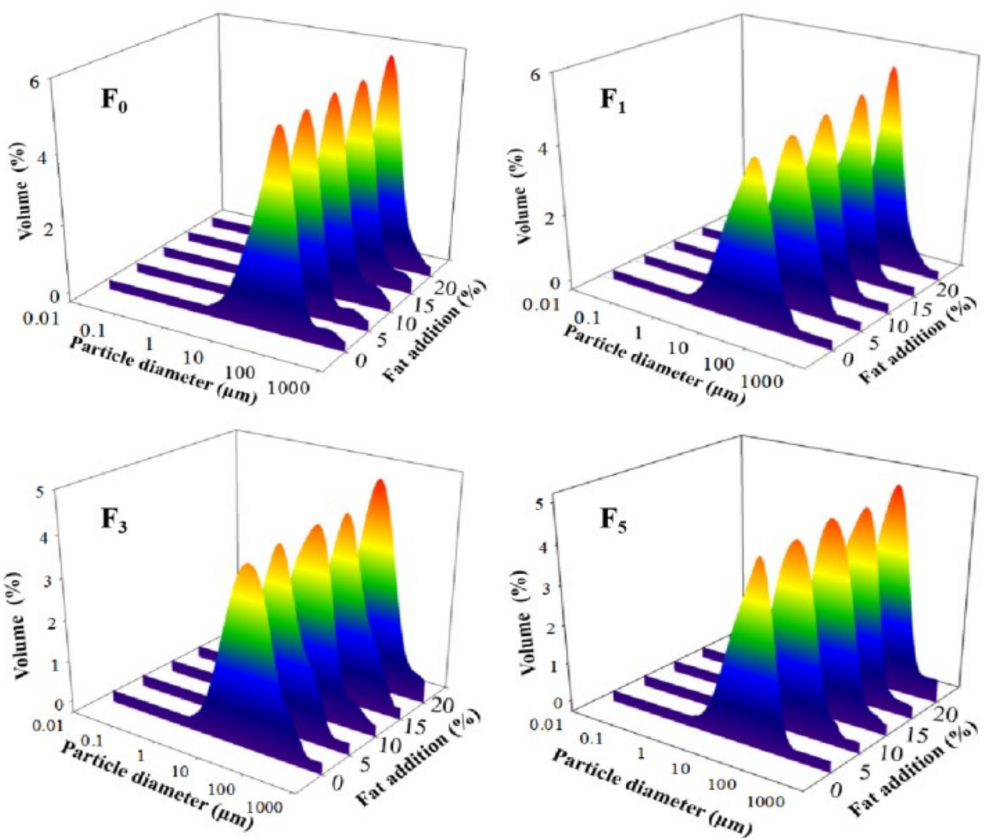

Figure 2. Influence of F-T cycles on volume-based particle size distribution of myofibrillar protein from quick-frozen patties with different fat levels. $\mathrm{F}_{0}, \mathrm{~F}_{1}, \mathrm{~F}_{3}$ and $\mathrm{F}_{5}$ means different $\mathrm{F}-\mathrm{T}$ cycles. 
Table 1. Influence of F-T cycles on particle size $\left(d_{4,3}\right.$ and $\left.d_{3,2}\right)$ of myofibrillar protein from quick-frozen patties with different fat levels.

\begin{tabular}{|c|c|c|c|c|c|c|}
\hline \multirow{2}{*}{$\begin{array}{c}\text { Particle } \\
\text { Size }(\mu \mathrm{m})\end{array}$} & \multirow{2}{*}{$\begin{array}{c}\text { F-T } \\
\text { Cycles }\end{array}$} & \multicolumn{5}{|c|}{ Fat Levels (\%) } \\
\hline & & 0 & 5 & 10 & 15 & 20 \\
\hline \multirow{4}{*}{$d_{4,3}$} & $\mathrm{~F}_{0}$ & $41.29 \pm 0.21^{\mathrm{Da}}$ & $41.25 \pm 0.22 \mathrm{Da}$ & $41.36 \pm 0.21 \mathrm{Da}$ & $41.45 \pm 0.37^{\mathrm{Da}}$ & $41.33 \pm 0.37^{\mathrm{Da}}$ \\
\hline & $\mathrm{F}_{1}$ & $44.19 \pm 0.61$ Cc & $45.39 \pm 0.41 \mathrm{Cb}$ & $46.13 \pm 0.14^{\mathrm{Cab}}$ & $46.76 \pm 0.28 \mathrm{Ca}$ & $47.05 \pm 0.53 \mathrm{Ca}$ \\
\hline & $\mathrm{F}_{3}$ & $47.45 \pm 0.51^{\mathrm{Bd}}$ & $48.52 \pm 0.41^{\mathrm{Bc}}$ & $49.61 \pm 0.31^{\mathrm{Bb}}$ & $50.95 \pm 0.09 \mathrm{Ba}$ & $51.61 \pm 0.25^{\mathrm{Ba}}$ \\
\hline & $\mathrm{F}_{5}$ & $50.49 \pm 0.43 \mathrm{Ad}$ & $52.49 \pm 0.43^{\mathrm{Ac}}$ & $53.49 \pm 0.43^{\mathrm{Ac}}$ & $54.54 \pm 0.27 \mathrm{Ab}$ & $56.54 \pm 0.26 \mathrm{Aa}$ \\
\hline \multirow{4}{*}{$d_{3,2}$} & $\mathrm{~F}_{0}$ & $12.32 \pm 0.17^{\mathrm{Da}}$ & $12.27 \pm 0.19^{\mathrm{Da}}$ & $12.21 \pm 0.14^{\mathrm{Da}}$ & $12.23 \pm 0.21 \mathrm{Da}$ & $12.21 \pm 0.14^{\mathrm{Da}}$ \\
\hline & $\mathrm{F}_{1}$ & $14.62 \pm 0.31 \mathrm{Cd}$ & $15.23 \pm 0.21 \mathrm{Ccd}$ & $15.66 \pm 0.24 \mathrm{Cbc}$ & $16.19 \pm 0.07^{\mathrm{Cab}}$ & $16.69 \pm 0.24^{\mathrm{Ca}}$ \\
\hline & $\mathrm{F}_{3}$ & $17.29 \pm 0.12 \mathrm{Be}$ & $17.78 \pm 0.14^{\mathrm{Bd}}$ & $18.34 \pm 0.08^{\mathrm{Bc}}$ & $18.81 \pm 0.18^{\mathrm{Bb}}$ & $19.35 \pm 0.23^{\mathrm{Ba}}$ \\
\hline & $\mathrm{F}_{5}$ & $19.53 \pm 0.21 \mathrm{Ae}$ & $20.51 \pm 0.17 \mathrm{Ad}$ & $21.61 \pm 0.12^{\mathrm{Ac}}$ & $22.37 \pm 0.23^{\mathrm{Ab}}$ & $23.38 \pm 0.26^{\mathrm{Aa}}$ \\
\hline
\end{tabular}

Values are given as the mean \pm SE. The means for the same fat levels with different uppercase letters (A-D) and the same F-T cycles with different lowercase letters (a to e) differed significantly $(p<0.05)$.

\subsubsection{Zeta Potential}

The net surface charge of proteins can be evaluated using zeta potential [43]. Figure $3 \mathrm{~A}$ shows changes in the zeta potential of protein from samples with different fat levels and multiple F-T cycles. All samples exhibited a negative charge, which was attributed to negatively charged amino acid residues (glutamic and aspartic acids) [34,44]. When the number of F-T cycles increased to five, the absolute value of protein zeta potential significantly decreased by $46.18 \%$ in samples with $20 \%$ fat $(p<0.05)$. The lower absolute zeta potential could be relevant to larger particle size in samples with $20 \%$ fat, thus leading to particle agglomeration between proteins. The results could be explained by the fact that the partial unfolding of proteins and protein aggregation during F-T cycles led to an imbalance in the proportion of acids and basic amino acids, which led to the change in net surface charge [45]. Vate and Benjakul [46] reported that proteins with lower absolute zeta potential had a smaller repulsive force between particles, which made aggregation easier. Furthermore, the formation of aggregate influenced the surface charge of proteins. Shen et al. [36] reported that the generation of a number of polymers due to the instability of protein solution reduced the protein molecules' exposed surface charges. The results agreed with the observed change in protein solubility (Figure 1B), which confirmed that F-T treatments and fat levels increased the instability of protein solutions.

\subsubsection{Protein Turbidity}

Turbidity changes are important for evaluating the state of protein aggregation [24]. As shown in Figure 3B, as the number of F-T cycles increased, the turbidity of samples significantly increased at the same fat level $(p<0.05)$. The results could be explained by the fact that protein conformation unfolding due to the exposure of hydrophobic residues during F-T cycles could promote protein-protein interactions and the formation of large protein aggregates [3]. Wang et al. [40] reported that the increased turbidity could be explained by the fact that the monomeric protein converted to a number of macromolecular proteins by polymerization. Li et al. [47] concluded a similar result that the destruction of protein conformation and exposure of hydrophobic groups led to the formation of high-molecular-weight aggregates, which then led to an increase in protein turbidity. Sow et al. [48] obtained similar results that the unfolding of protein structure could facilitate aggregation, which resulted in an increase in turbidity.

When samples underwent the same number of F-T cycles, the turbidity of MP significantly increased as fat levels increased $(p<0.05)$. For samples with $20 \%$ fat at the fifth F-T cycle, the changes in turbidity significantly increased by $20.93 \%$ compared with those in patties without fat. The results could be explained by the fact that lipid oxidation could have aggravated the extent of protein oxidation during F-T cycles, which induced protein denaturation and promoted the formation of large aggregates, thus increasing the turbidity of MP suspensions [36]. The turbidity differences from different fat levels might be related 
to the disparity in the rate and degree of protein aggregation, as samples with higher fat levels possibly formed large protein aggregates. The turbidity of MP suspension could be confirmed with an increase in surface hydrophobicity (Figure 1A) and a decrease in protein solubility (Figure 1B).
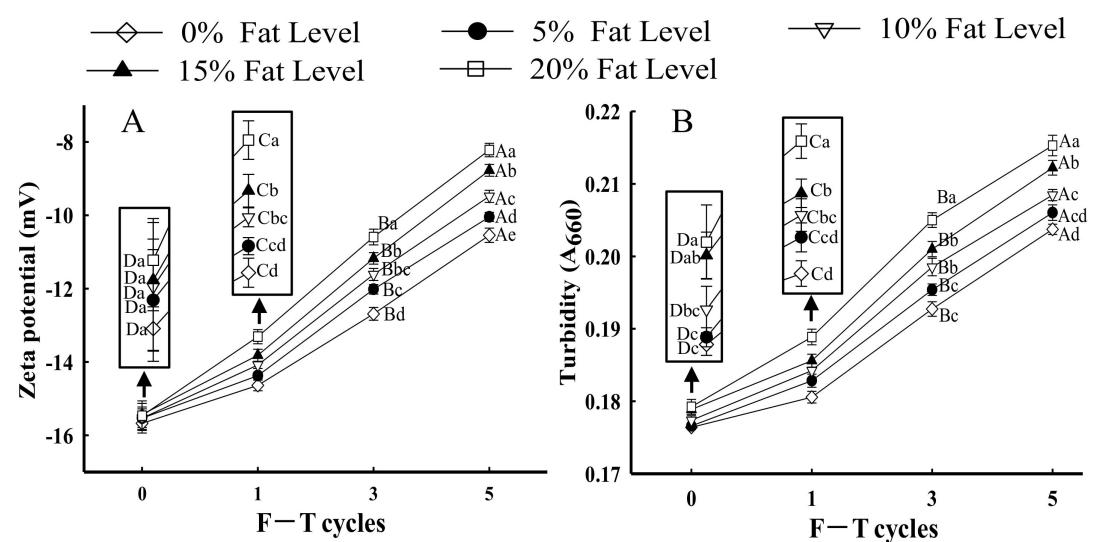

Figure 3. Influence of F-T cycles on zeta potential (A) and turbidity (B) of myofibrillar protein from quick-frozen patties with different fat levels. Values are given as the mean $\pm \mathrm{SE}$. The means for the same fat levels with different uppercase letters (A to D) and the same F-T cycles with different lowercase letters (a to e) differed significantly $(p<0.05)$.

\subsection{Emulsifying Property}

\subsubsection{EAI and ESI}

The emulsifying property shows the ability of protein to adsorb at the oil-water interface, which can be evaluated using EAI and ESI [24]. As depicted in Figure 4A,B, the EAI and ESI of MP from samples with the same F-T cycles were significantly lesser with greater levels of fat $(p<0.05)$. The reduction in EAI and ESI of MP could be explained by the fact that the formation of intra-/intermolecular disulfide bonds and oxidative reactions induced by F-T processes led to a less stable protein conformation, which prevented the formation of stable emulsions [49,50]. Moreover, when the samples with $20 \%$ fat levels were at the fifth F-T cycle, the EAI and ESI of MP significantly declined by 26.73 and $14.15 \%$, respectively, compared with those of MP from patties without fat. The results could be attributed to proteins from patties with higher amounts of fat being more prone to denaturation and easily forming large insoluble aggregates. Note that the formation of large protein aggregates caused fewer protein molecules to be adsorbed at the oil-water interface, which led to a decrease in the EAI and ESI of MP [51]. Furthermore, Zhang et al. [20] demonstrated that aggregates might reduce the flexibility of protein to adsorb at the surface of lipid droplets, thus decreasing emulsifying properties. The result was associated with a change in particle size (Figure 2) in which a larger particle size had a negative influence on emulsifying ability and stability.

\subsubsection{Microstructure of Emulsion}

Figure $4 \mathrm{C}$ shows optical micrographs of emulsion droplet distribution and size prepared with different samples under F-T cycles. The droplets of fresh samples exhibited a relatively small and homogeneous shape, and the average diameter of droplets was $10.13 \mu \mathrm{m}$. As fat levels and the number of F-T cycles increased, larger oil droplets were formed. Moreover, oil flocculation, dense and irregular distribution of emulsion droplets, was observed. The droplet size was increased to $18.67(0 \%), 19.12(5 \%), 20.83(10 \%), 23.08$ $(15 \%)$, and $24.96 \mu \mathrm{m}(20 \%)$ after five F-T cycles. The phenomenon agreed with the change in particle size (Figure 2) and emulsifying properties (Figure 4A,B). The results could be explained by the fact that freezing and thawing processes, along with oxidative reactions, decreased the emulsifying properties of the protein and promoted the formation of aggregates between protein molecules [51]. 

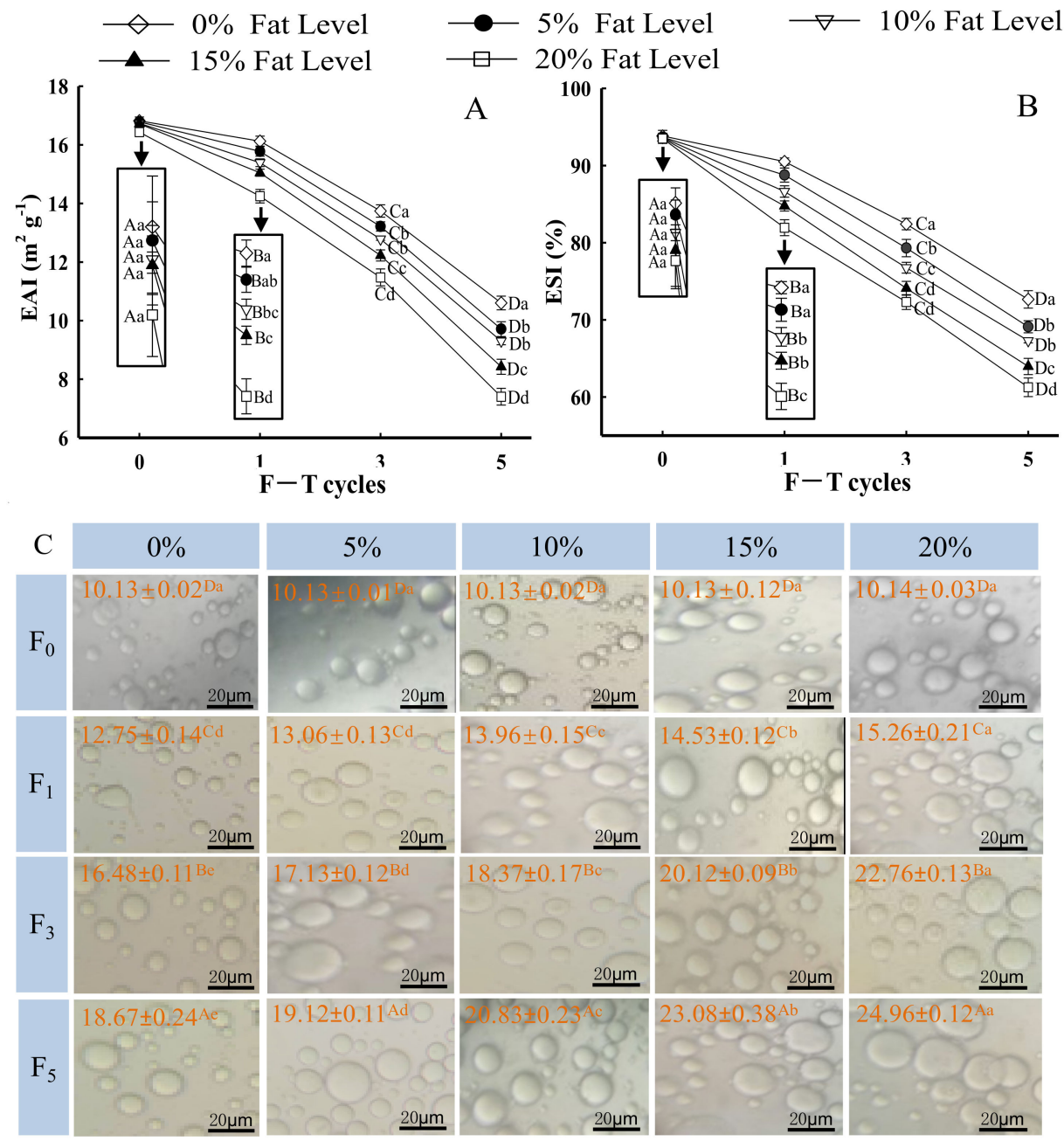

Figure 4. Influence of F-T cycles on emulsifying activity index (EAI) (A), emulsifying stability index (ESI) (B), the diameter of myofibrillar protein emulsion droplets $(\mu \mathrm{m})$ and the distribution $(C)$ of myofibrillar protein from quick-frozen patties with different fat levels. The magnification was set as $\times 40$. Values are given as the mean \pm SE. The means for the same fat levels. with different uppercase letters (A to D) and the same F-T cycles with different lowercase letters (a to e) differ significantly $(p<0.05)$.

\subsection{Correlation Analysis}

PCA analysis was performed to establish the correlations between the indicators (surface hydrophobicity, protein solubility, $d_{4,3}, d_{3,2}$ zeta potential, protein turbidity droplet diameter, EAI and ESI) as well as between the indicators and different F-T cycles (as shown in Table 2 and Figure 5).

As shown in Table 2, correlation analysis showed that the surface hydrophobicity was negatively related to EAI and ESI and that this appeared to be extremely significant correlation $(p<0.01)$. Protein solubility was positively related to EAI and ESI. Xia et al. [27] indicated that protein with higher surface hydrophobicity could lower the protein solubility and promote protein denaturation and aggregation. The formation of protein aggregates caused fewer protein molecules to be adsorbed at the oil-water interface, leading to a decrease in the EAI and ESI of MP. Moreover, $d_{4,3}, d_{3,2}$, droplet size, turbidity, and zeta potential were extremely correlated with EAI and ESI $(p<0.01)$. An increase in the particle size and protein turbidity might exacerbate protein-protein interactions and facilitate the formation of large protein aggregates [3]. The formation of aggregates might lower the protein capacity to adsorb at the surface of lipid droplets, thus resulting in a decrease in emulsifying ability [20]. 
Figure 5 shows score plots for the principal components (PC1 and PC2), the first two principal components, which explained about $98.54 \%$ and $0.78 \%$ of the overall variance, respectively. The changes in protein properties can be inferred to be located in designated quadrants 1, 2, 3, and 4. As shown in Figure 5A, EAI, ESI, and protein solubility of samples were distributed in the negative part of PC1, while droplet diameter, surface hydrophobicity, $d_{4,3}, d_{3,2}$, protein turbidity, and zeta potential were distributed in the positive side of PC1, indicating that EAI and ESI were positively correlated with protein solubility but negatively correlated with droplet diameter, surface hydrophobicity, $d_{4,3}, d_{3,2}$, protein turbidity, and zeta potential. The results are also shown in Table 2. Figure 5B shows differentiations among the samples under different $\mathrm{F}-\mathrm{T}$ cycles. The samples could be separated into two groups. The first group consisted of $\mathrm{F}_{0}(0 \%, 5 \%, 10 \%, 15 \%$, and $20 \%)$ and $\mathrm{F}_{1}(0 \%, 5 \%, 10 \%$, $15 \%$, and $20 \%$ ) samples. The two samples were distributed in the left quadrant, and they were positively correlated with EAI, ESI, and protein solubility. When the samples were in the $F_{0}$ and $F_{1}$ cycles, the damage to protein structure was relatively small. Thus, protein had a relatively high solubility and could be adsorbed at the oil-water interface. The second group consisted of $\mathrm{F}_{3}(0 \%, 5 \%, 10 \%, 15 \%$, and $20 \%)$ and $\mathrm{F}_{5}(0 \%, 5 \%, 10 \%, 15 \%$, and $20 \%$ ) samples. The two samples were distributed in the right quadrant, and they were positively correlated with droplet diameter, surface hydrophobicity, $d_{4,3}, d_{3,2}$, protein turbidity, and zeta potential. When patties were subjected to repeated F-T cycles, protein conformation was unfolded, and certain hydrophobic groups were exposed to the polar environments of the protein, which subsequently participated in the processes of protein aggregation. As a result, the degree of protein denaturation and aggregation was increased with increased numbers of F-T cycles, and the effects on protein turbidity and zeta potential were more significant at the fifth F-T cycle.

Table 2. Correlations among protein denaturation, protein aggregation, and the emulsifying property of MP from samples with different fat levels and F-T cycles.

\begin{tabular}{|c|c|c|c|c|c|c|c|c|c|}
\hline & $\begin{array}{c}\text { Surface } \\
\text { Hydrophobicity }\end{array}$ & $\begin{array}{l}\text { Protein } \\
\text { Solubility }\end{array}$ & $d_{4,3}$ & $d_{3,2}$ & $\begin{array}{c}\text { Zeta } \\
\text { Potential }\end{array}$ & $\begin{array}{l}\text { Protein } \\
\text { Turbidity }\end{array}$ & $\begin{array}{c}\text { Droplet } \\
\text { Diameter }\end{array}$ & EAI & ESI \\
\hline $\begin{array}{l}\text { Surface } \\
\text { hydrophobicity }\end{array}$ & 1 & & & & & & & & \\
\hline Protein solubility & $-0.984 * *$ & 1 & & & & & & & \\
\hline$d_{4,3}$ & $0.983^{* *}$ & -0.986 ** & 1 & & & & & & \\
\hline$d_{3,2}$ & 0.971 ** & $-0.983^{* *}$ & $0.997^{* *}$ & 1 & & & & & \\
\hline Zeta potential & $0.973 * *$ & $-0.995^{* *}$ & $0.988 * *$ & $0.989^{* *}$ & 1 & & & & \\
\hline Protein turbidity & 0.972 ** & $-0.994 * *$ & $0.983 * *$ & 0.981 ** & $0.998 * *$ & 1 & & & \\
\hline Droplet diameter & $0.987^{* *}$ & $-0.985^{* *}$ & 0.983 ** & $0.974 * *$ & $0.977^{* *}$ & $0.979 * *$ & 1 & & \\
\hline EAI & $-0.960 * *$ & $0.987^{* *}$ & $-0.972 * *$ & $-0.976^{* *}$ & $-0.992 * *$ & $-0.989 * *$ & $-0.951 * *$ & 1 & \\
\hline ESI & $-0.980 * *$ & $0.995^{* *}$ & $-0.991^{* *}$ & $-0.990 * *$ & $-0.997^{* *}$ & $-0.995^{* *}$ & $-0.977^{* *}$ & $0.991 * *$ & 1 \\
\hline
\end{tabular}

Note: ${ }^{* *}$, extremely significant correlation $(p<0.01)$. Minus signs indicate that the corresponding indicators are negatively correlated; their absence indicates that the corresponding indicators are positively correlated.

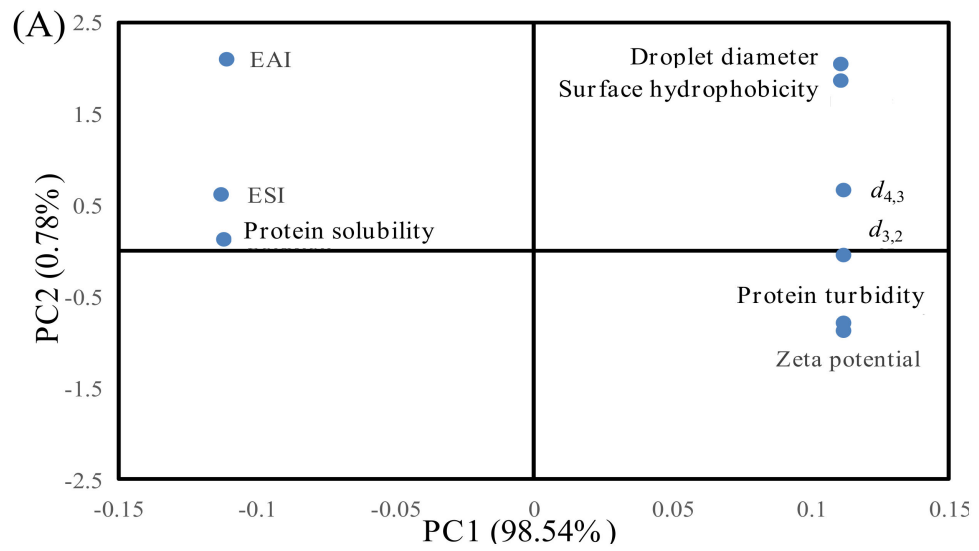

Figure 5. Cont. 
(B)

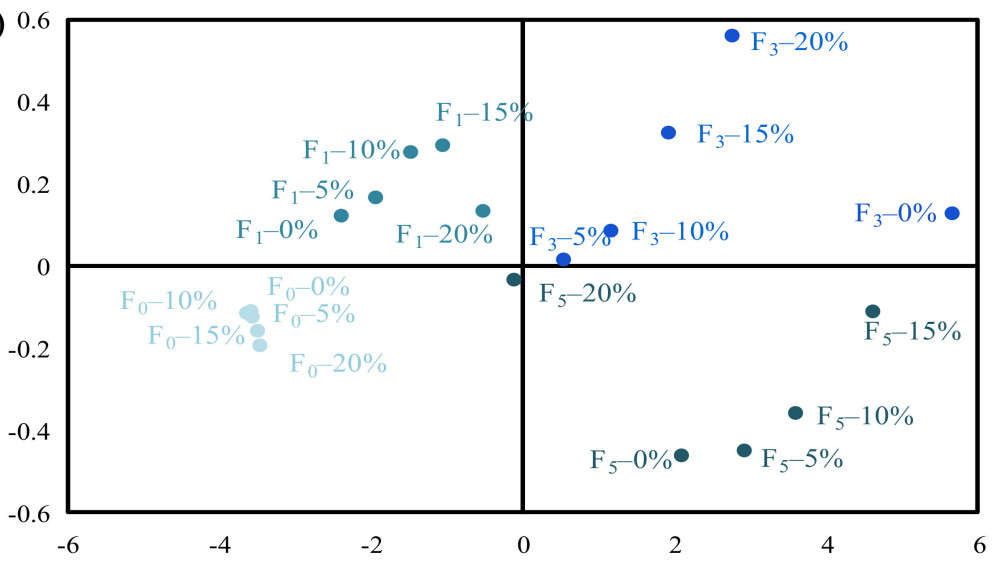

Figure 5. Principal component analysis (PCA) of the indicators and patties at different F-T cycles. Weighed PCA biplot of (A) factor loading plot and (B) factor scores plot for the first two principal components, accounting for approximately $99.32 \%$ of the total variance of the data. PC1 describes $98.54 \%$ of the variation, and PC2 explains $0.78 \%$.

\subsection{Possible Mechanism Schematic for Decreased Emulsifying Performance}

The decrease in the MP emulsifying property because of protein aggregation and denaturation was demonstrated by the aforementioned results (as shown in Sections 3.1-3.3) in our study. Furthermore, a schematic was proposed and is exhibited in Figure 6. Myosin is the major protein in myofibrils and has a relatively strong ability to adsorb on emulsion droplets [2]. For the $\mathrm{F}_{0}$ samples, myosin in solution positioned the head of the aqueous phase and positioned the rod-like tail in the oil phase. The emulsion droplets were evenly distributed in the solution, and shape was homogeneous. During freezing and thawing processes, myosin gradually unfolded, which was followed by the subsequent exposure of buried polar and hydrophobic groups. Consequently, the sulfhydryl groups in the head of myosin were easily oxidized, which triggered the formation of protein aggregates [11]. The aggregate formation reduced the ability of the protein to adsorb at the oil-water interface, causing a reduction in emulsifying performance. Furthermore, the increase in the content of denatured protein triggered irregular distribution and flocculation of emulsion droplets, which caused a reduction in the emulsifying property of MP.

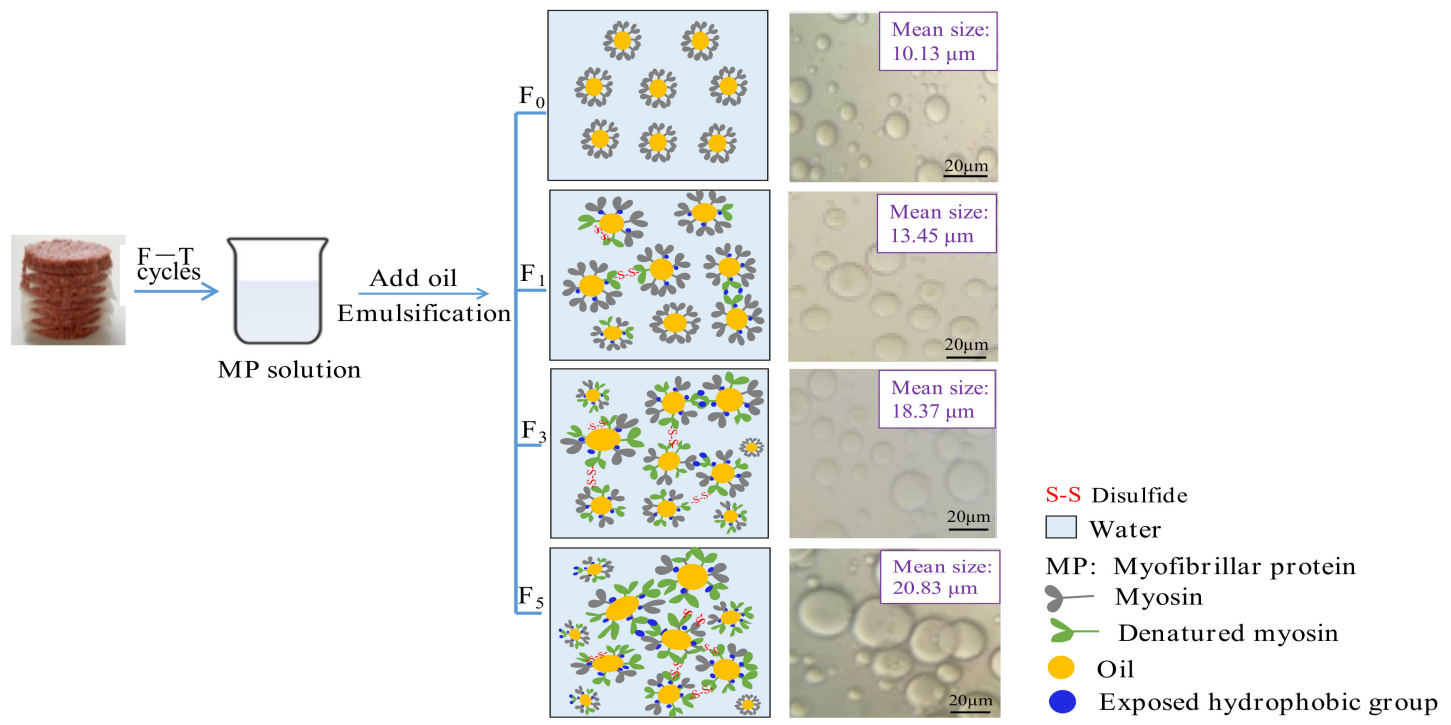

Figure 6. Proposed schematic illustration for the decreased emulsifying property of protein during F-T cycles caused by protein aggregation and denaturation. 


\section{Conclusions}

With increased fat levels and F-T cycles of patties, protein denaturation and aggregation increased, which was demonstrated by increases in surface hydrophobicity, turbidity, and particle size, in addition to reductions in solubility and the absolute zeta potential of proteins. Patties with higher fat levels could aggravate the extent of protein denaturation and aggregation, which thus weakened the emulsifying property in terms of reduced EAI and ESI and the increased size of emulsion droplets. To summarize, protein denaturation and aggregation demonstrated a negative impact on the emulsifying property of quick-frozen patties after multiple F-T cycles.

Author Contributions: Methodology, software, and writing-original draft preparation, N.P.; conceptualization, W.W.; investigation and validation, X.D. and H.L.; formal analysis, B.K.; resources, data curation, and writing-review and editing, Q.L.; visualization, supervision, and project administration, F.L.; funding acquisition, X.X. All authors have read and agreed to the published version of the manuscript.

Funding: This study was supported by the National Natural Science Foundation of China (grant no. 32172273 and 31771903).

Institutional Review Board Statement: Not applicable.

Informed Consent Statement: Not applicable.

Data Availability Statement: The data presented in this study are available in the article.

Conflicts of Interest: The authors declare no conflict of interest.

\section{References}

1. Zhao, Y.; Hou, Q.; Cao, S.; Wang, Y.; Zhou, G.; Zhang, W. Effect of regenerated cellulose fiber on the properties and microstructure of emulsion model system from meat batters. Food Hydrocoll. 2019, 87, 83-89. [CrossRef]

2. Li, K.; Fu, L.; Zhao, Y.; Xue, S.; Wang, P.; Xu, X.; Bai, Y. Use of high-intensity ultrasound to improve emulsifying properties of chicken myofibrillar protein and enhance the rheological properties and stability of the emulsion. Food Hydrocoll. 2020, $98,105275$. [CrossRef]

3. Zhang, M.; Li, F.; Diao, X.; Kong, B.; Xia, X. Moisture migration, microstructure damage and protein structure changes in porcine longissimus muscle as influenced by multiple freeze-thaw cycles. Meat Sci. 2017, 133, 10-18. [CrossRef] [PubMed]

4. Zhao, Y.; Hou, Q.; Zhuang, X.; Wang, Y.; Zhou, G.; Zhang, W. Effect of regenerated cellulose fiber on the physicochemical properties and sensory characteristics of fat-reduced emulsified sausage. LWT-Food Sci. Technol. 2018, 97, 157-163. [CrossRef]

5. Kim, T.K.; Yong, H.I.; Jung, S.; Kim, Y.B.; Choi, Y.S. Effects of replacing pork fat with grape seed oil and gelatine/alginate for meat emulsions. Meat Sci. 2020, 163, 108079. [CrossRef]

6. Donato, L.; Guyomarc'h, F.; Amiot, S.; Dalgleish, D.G. Formation of whey protein/ k-casein complexes in heated milk: Preferential reaction of whey protein with k-casein in the casein micelles. Int. Dairy J. 2007, 17, 1161-1167. [CrossRef]

7. Chandrapala, J.; Augustin, M.A.; Mckinnon, I.; Udabage, P. Effects of $\mathrm{pH}$, calcium-complexing agents and milk solids concentration on formation of soluble protein aggregates in heated reconstituted skim milk. Int. Dairy J. 2010, 20, 777-784. [CrossRef]

8. Xu, W.; Nikolov, A.; Wasan, D.T. Shear-induced fat particle structure variation and the stability of food emulsions: II. Effects of surfactants, protein, and fat substitutes. J. Food Eng. 2005, 66, 107-116. [CrossRef]

9. Feng, H.; Jin, H.; Gao, Y.; Yan, S.; Zhang, Y.; Zhao, Q.; Xu, J. Effects of freeze-thaw cycles on the structure and emulsifying properties of peanut protein isolates. Food Chem. 2020, 330(7), 127215. [CrossRef]

10. Wang, B.; Li, F.; Pan, N.; Kong, B.; Xia, X. Effect of ice structuring protein on the quality of quick-frozen patties subjected to multiple freeze-thaw cycles. Meat Sci. 2021, 172, 108335. [CrossRef]

11. Wang, B.; Kong, B.; Li, F.; Liu, Q.; Zhang, H.; Xia, X. Changes in the thermal stability and structure of protein from porcine longissimus dorsi induced by different thawing methods. Food Chem. 2020, 316, 126375. [CrossRef] [PubMed]

12. Ali, S.; Zhang, W.; Rajput, N.; Khan, M.; Li, C.; Zhou, G. Effect of multiple freeze-thaw cycles on the quality of chicken breast meat. Food Chem. 2015, 173, 808-814. [CrossRef] [PubMed]

13. Pan, N.; Dong, C.; Du, X.; Kong, B.; Sun, J.; Xia, X. Effect of freeze-thaw cycles on the quality of quick-frozen pork patty with different fat content by consumer assessment and instrument-based detection. Meat Sci. 2021, 172, 108313. [CrossRef] [PubMed]

14. Li, F.; Wang, B.; Liu, Q.; Chen, Q.; Zhang, H.; Xia, X.; Kong, B. Changes in myofibrillar protein gel quality of porcine longissimus muscle induced by its structural modification under different thawing methods. Meat Sci. 2019, 147, 108-115. [CrossRef] [PubMed]

15. Li, F.; Zhong, Q.; Kong, B.; Wang, B.; Pan, N.; Xia, X. Deterioration in quality of quick-frozen pork patties induced by changes in protein structure and lipid and protein oxidation during frozen storage. Food Res. Int. 2020, 133, 109142. [CrossRef] [PubMed] 
16. Pan, N.; Hu, Y.; Li, Y.; Ren, Y.; Kong, B.; Xia, X. Changes in the thermal stability and structure of myofibrillar protein from quick-frozen pork patties with different fat addition under freeze-thaw cycles. Meat Sci. 2021, 175, 108420. [CrossRef] [PubMed]

17. Benjakul, S.; Seymour, T.; Morrissey, M.T.; Haejung, A. Physicochemical changes in pacific whiting muscle proteins during iced storage. J. Food Sci. 1997, 62, 729-733. [CrossRef]

18. Wang, X.; Xiong, Y.; Sato, H. Rheological enhancement of pork myofibrillar protein-lipid emulsion composite gels via glucose oxidase oxidation/transglutaminase cross-linking pathway. J. Agric. Food Chem. 2017, 65, 24-30. [CrossRef]

19. Pan, J.; Lian, H.; Jia, H.; Li, S.; Hao, R.; Wang, Y.; Zhang, X.; Dong, X. Ultrasound treatment modified the functional mode of gallic acid on properties of fish myofibrillar protein. Food Chem. 2020, 320, 126637. [CrossRef]

20. Zhang, C.; Liu, H.; Xia, X.; Sun, F.; Kong, B. Effect of ultrasound-assisted immersion thawing on emulsifying and gelling properties of chicken myofibrillar protein. LWT-Food Sci. Technol. 2021, 142, 111016. [CrossRef]

21. Pearce, K.N.; Kinsella, J.E. Emulsifying properties of proteins: Evaluation of a turbidimetric technique. J. Agric. Food Chem. 1978, 26, 716-723. [CrossRef]

22. Cao, J.; Zhou, C.; Wang, Y.; Sun, Y.; Pan, D. The effect of oxidation on the structure of G-actin and its binding ability with aroma compounds in carp grass skeletal muscle. Food Chem. 2018, 240, 346-353. [CrossRef] [PubMed]

23. Xu, Y.; Dong, M.; Tang, C.; Han, M.; Xu, X.; Zhou, G. Glycation-induced structural modification of myofibrillar protein and its relation to emulsifying properties. LWT-Food Sci. Technol. 2020, 117, 108664. [CrossRef]

24. Jia, N.; Zhang, F.; Liu, Q.; Wang, L.; Lin, S.; Liu, D. The beneficial effects of rutin on myofibrillar protein gel properties and related changes in protein conformation. Food Chem. 2019, 301, 125206. [CrossRef] [PubMed]

25. Li, L.; Zhao, X.; Xu, X. Trace the difference driven by unfolding-refolding pathway of myofibrillar protein: Emphasizing the changes on structural and emulsion properties. Food Chem. 2022, 367, 130688. [CrossRef]

26. Fu, Q.; Liu, R.; Wang, H.; Hua, C.; Song, S.; Zhou, G.; Zhang, W. Effects of oxidation in vitro on structures and functions of myofibrillar protein from beef muscles. J. Agric. Food Chem. 2019, 67, 5866-5873. [CrossRef]

27. Xia, X.; Kong, B.; Xiong, Y.; Ren, Y. Decreased gelling and emulsifying properties of myofibrillar protein from repeatedly frozen-thawed porcine longissimus muscle are due to protein denaturation and susceptibility to aggregation. Meat Sci. 2010, 85, 481-486. [CrossRef]

28. Shi, S.; Feng, J.; An, G.; Kong, B.; Wang, H.; Pan, N.; Xia, X. Dynamics of heat transfer and moisture in beef jerky during hot air drying. Meat Sci. 2021, 182, 108638. [CrossRef]

29. Riebroy, S.; Benjakul, S.; Visessanguan, W.; Erikson, U.; Rustad, T. Acid-induced gelation of natural actomyosin from atlantic cod (Gadus morhua) and burbot (Lota lota). Food Hydrocoll. 2009, 23, 26-39. [CrossRef]

30. Du, L.; Betti, M. Chicken collagen hydrolysate cryoprotection of natural actomyosin: Mechanism studies during freeze-thaw cycles and simulated digestion. Food Chem. 2016, 211, 791-802. [CrossRef]

31. Du, X.; Zhao, M.; Pan, N.; Wang, S.; Xia, X.; Zhang, D. Tracking aggregation behaviour and gel properties induced by structural alterations in myofibrillar protein in mirror carp (Cyprinus carpio) under the synergistic effects of $\mathrm{pH}$ and heating. Food Chem. 2021, 362, 130222. [CrossRef]

32. Li, F.; Wang, B.; Kong, B.; Shi, S.; Xia, X. Decreased gelling properties of protein in mirror carp (Cyprinus carpio) are due to protein aggregation and structure deterioration when subjected to freeze-thaw cycles. Food Hydrocoll. 2019, 97, 105-223. [CrossRef]

33. Ge, J.; Sun, C.; Mata, A.; Corke, H.; Gan, R.; Fang, Y. Physicochemical and pH-dependent functional properties of proteins isolated from eight traditional Chinese beans. Food Hydrocoll. 2021, 112, 106288. [CrossRef]

34. Cao, Y.; Ma, W.; Huang, J.; Xiong, Y. Effects of sodium pyrophosphate coupled with catechin on the oxidative stability and gelling properties of myofibrillar protein. Food Hydrocoll. 2020, 104, 105722. [CrossRef]

35. Zhou, Y.; Yang, H. Enhancing tilapia fish myosin solubility using proline in low ionic strength solution. Food Chem. 2020, 320, 126665. [CrossRef] [PubMed]

36. Shen, H.; Elmore, J.; Zhao, M.; Sun, W. Effect of oxidation on the gel properties of porcine myofibrillar proteins and their binding abilities with selected flavour compounds. Food Chem. 2020, 329, 127032. [CrossRef]

37. Lv, Y.; Feng, X.; Yang, R.; Qian, S.; Liu, Y.; Xu, X. Dual role (promotion and inhibition) of transglutaminase in mediating myofibrillar protein gelation under malondialdehyde-induced oxidative stress. Food Chem. 2021, 353, 129453. [CrossRef] [PubMed]

38. Li, H.; Hu, Y.; Zhao, X.; Wan, W.; Du, X.; Kong, B.; Xia, X. Effects of different ultrasound powers on the structure and stability of protein from sea cucumber gonad. LWT-Food Sci. Technol. 2021, 137, 110403. [CrossRef]

39. Bao, Z.; Wu, J.; Cheng, Y.; Chi, Y. Effects of lipid peroxide on the structure and gel properties of ovalbumin. Process. Biochem. 2017, 57, 124-130. [CrossRef]

40. Wang, B.; Du, X.; Kong, B.; Liu, Q.; Li, F.; Pan, N.; Xia, X. Effect of ultrasound thawing, vacuum thawing, and microwave thawing on gelling properties of protein from porcine longissimus dorsi. Ultrason. Sonochem. 2020, 64, 104860. [CrossRef]

41. Wang, Y.; Rashid, M.; Yan, J.; Ma, H. Effect of multi-frequency ultrasound thawing on the structure and rheological properties of myofibrillar proteins from small yellow croaker. Ultrason. Sonochem. 2021, 70, 105352. [CrossRef] [PubMed]

42. Wang, Y.; Yan, J.; Ding, Y.; Rashid, M.; Ma, H. Effect of sweep frequency ultrasound and fixed frequency ultrasound thawing on gelling properties of myofibrillar protein from quick-frozen small yellow croaker and its possible mechanisms. LWT-Food Sci. Technol. 2021, 150, 111922. [CrossRef] 
43. Wu, F.; Shi, X.; Zou, H.; Zhang, T.; Dong, X.; Zhu, R.; Yu, C. Effects of high-pressure homogenization on physicochemical, rheological and emulsifying properties of myofibrillar protein. J. Food Eng. 2019, 263, 272-279. [CrossRef]

44. Li, F.; Du, X.; Ren, Y.; Kong, B.; Wang, B.; Xia, X.; Bao, Y. Impact of ice structuring protein on myofibrillar protein aggregation behaviour and structural property of quick-frozen patty during frozen storage. Int. J. Biol. Macromol. 2021, 178, 136-142. [CrossRef]

45. Chen, N.; Zhao, M.; Sun, W.; Ren, J.; Cui, C. Effect of oxidation on the emulsifying properties of soy protein isolate. Food Res. Int. 2013, 52, 26-32. [CrossRef]

46. Vate, N.; Benjakul, S. Combined effect of squid ink tyrosinase and tannic acid on heat induced aggregation of natural actomyosin from sardine. Food Hydrocoll. 2016, 56, 62-70. [CrossRef]

47. Li, F.; Du, X.; Wang, B.; Pan, N.; Xia, X.; Bao, Y. Inhibiting effect of ice structuring protein on the decreased gelling properties of protein from quick-frozen pork patty subjected to frozen storage. Food Chem. 2021, 353, 129104. [CrossRef]

48. Sow, L.C.; Toh, Z.Y.; Wong, C.; Yang, H. Combination of sodium alginate with tilapia fish gelatin for improved texture properties and nanostructure modification. Food Hydrocoll. 2019, 94, 459-467. [CrossRef]

49. Chen, H.; Kong, B.; Guo, Y.; Xia, X.; Diao, X.; Li, P. The effectiveness of cryoprotectants in inhibiting multiple freeze-thaw induced functional and rheological changes in the myofibrillar proteins of common carp (Cyprinus carpio) surimi. Food Biophys. 2013, 8 , 302-310. [CrossRef]

50. Li, Y.; Kong, B.; Xia, X.; Liu, Q.; Diao, X. Structural changes of the myofibrillar proteins in common carp (Cyprinus carpio) muscle exposed to a hydroxyl radical-generating system. Process. Biochem. 2013, 48, 863-870. [CrossRef]

51. Ma, X.; Yan, T.; Hou, F.; Chen, W.; Miao, S.; Liu, D. Formation of soy protein isolate (SPI)-citrus pectin (CP) electrostatic complexes under a high-intensity ultrasonic field: Linking the enhanced emulsifying properties to physicochemical and structural properties. Ultrason. Sonochem. 2019, 59, 104748. [CrossRef] [PubMed] 